\title{
Insulin, Diabetes, and Rewards for Discoveries.
}

\author{
By Sir W. M. Bayliss, F.R.S.
}

A NUMBER of problems, some of great scientific A interest, others of practical importance in various ways, have been brought to notice by the somewhat sensational statements in the daily press relating to the Canadian treatment of diabetes by a preparation extracted from the pancreas and known as "insulin" (see NatURE, November 25, p. 713 ; December 9, p. 774). In order to understand the state of affairs, it is necessary to review briefly our present knowledge of the physiological processes concerned with the utilisation of carbohydrate food. This will also serve to direct attention to gaps which need filling up, and the opportunities afforded by a trustworthy preparation of the hormone of the pancreatic "islets." If such a preparation shows itself to be of value in the treatment of diabetes in man, it is clear that difficulties of several kinds arise in the ensuring of an adequate commercial supply of an active product. We shall see further that the question of due rewards for discoveries which involve the cure of disease arises in the present case in an acute form.

If we look at tables drawn up to indicate a reasonable proportion between the constituents of a normal diet, we notice how large a part of the total energy required is supplied by carbohydrate. In that of the Royal Society Food Committee, for example, more than 65 per cent. is from this source. The justification is given by the fact that evidence of various kinds shows that the material from which muscle directly derives the energy for its activity in normal conditions is glucose. This is burned up with consumption of oxygen, while the products finally leave the body as carbon dioxide and water. Since measurements of the "Respiratory Quotient" in muscular work form a part of the evidence and are of importance in judging the properties of insulin, a word may be useful here as to the meaning of this number. If glucose is burned in the ordinary way in air, and the amount of oxygen consumed and of carbon dioxide and water produced is determined, the volume of carbon dioxide is found to be equal to that of the oxygen used. This is of course due to the fact that carbohydrate contains sufficient oxygen in its molecule to oxidise the hydrogen. Fat or protein, on the other hand, requires more oxygen, to burn part of the hydrogen as well as the carbon. The respiratory quotient expresses the ratio of the volume of the carbon dioxide produced to that of the oxygen consumed, so that if carbohydrate alone is burned, the value is unity, and it decreases in proportion to the amount of the fat or protein burned. If it rises, due attention being paid to absence of retention of carbon dioxide, we are justified in concluding that more carbohydrate is being oxidised.

Glucose is also known to be consumed in other organs - the secreting glands, for example-and probably in the tissues generally. It is supplied by the blood, although only present therein in very low concentration, about 0.1 to 0.15 per cent. Being a crystalloid and filtering through the glomeruli of the kidney, a large quantity would be lost were it not that as this filtrate flows along the renal tubules, the glucose is almost entirely reabsorbed, along with other con- stituents of value. If, however, the concentration of sugar in the blood rises above the normal value (hyperglycæmia), owing to a large amount of carbohydrate in the food, or an incapacity on the part of the tissues to consume it to the proper degree, then the absorptive power of the kidney is insufficient, and sugar appears in the urine (glycosuria). The glycosuria resulting from excess of blood-sugar owing to diet is in itself harmless; glucose is often added to gum-saline for intravenous injection in cases of traumatic shock. When glycosuria, on the other hand, is due to failure to consume glucose, we have the morbid state known as diabetes mellitus, in which there are involved other consequences of this defect, themselves giving rise to serious symptoms.

Since the supply of sugar from the digestive canal is intermittent and in excess of the immediate demand, while this demand is constant, it is clear that some means of storage is needed. This is provided by the liver, which deposits glucose in its cells in the form of the insoluble glycogen. From this store it is released as required. The muscular tissues, especially that of the heart, are also able to store glycogen to some extent. Now in diabetes it is found that the liver has lost this power, although the muscles retain it. It is not obvious why this loss of storage power in the liver should be connected with failure of the tissues generally to consume glucose, but so it is ; and there is another rather remarkable fact. If the food given to a diabetic animal is devoid of carbohydrate, glucose is produced from certain amino-acid components of proteins, although it is not utilised, and escapes in the urine. It may be that the consumption of glucose is never completely absent in diabetes, but is dependent on a high concentration in the blood. This minimal consumption being absolutely essential to life, it is provided from protein, if no other supply is available. Hence the great wasting of body substance present in diabetes.

In the year I889, a paper by Von Mering and Minkovski was published, in which it was shown that if the pancreas was removed from dogs, a condition like that of diabetes was produced. They found further that if a small piece of the pancreas had previously been grafted under the skin, removal of the rest of the pancreas was ineffective until this graft was also removed. It was also found that ligature of the ducts of the pancreas did not produce diabetes. These results pointed clearly to an internal secretion from the pancreas as being necessary for the utilisation of sugar. It was found that the residue of pancreatic tissue left in both the cases referred to consisted of the structures known as "Islets of Langerhans," and it was advocated by Sharpey Schafer that these organs are responsible for the internal secretion. Further evidence confirmed this view, although there are still some differences of opinion as to the independence of the islet tissue and the ordinary secreting tissues. The discovery of Diamare that in many teleostean fishes the islet tissue exists in organs separate from the pancreas is important evidence that this tissue is not in the adult formed from the pancreatic cells. In Lophius, according to Diamare, these masses of islet tissue may be as 
large as peas. But, for some reason or other, extracts of the pancreas have only occasionally been found to have any influence when given to diabetic animals. The active constituent is destroyed by some other substance, possibly trypsin, contained in such extracts.

Since the cells which produce trypsin degenerate after tying the ducts, it occurred to Dr. Banting, rather more than a year ago, that extracts of such organs might contain the active principle sought for, free from destruction. Dr. Banting was then in medical practice at London, Ontario, but gave up his practice and went to Prof. Macleod's laboratory at Toronto to make the necessary experiments on animals. Here he was joined by Mr. Best, an assistant in the laboratory, by Prof. Macleod himself, and at a later date by Dr. Collip and others. The experiments were successful. In another way it was found possible to prepare active extracts. It had been noticed that the presence of a fœtus protects the mother. The islet tissue, as it appears, begins to be functional at an earlier date than the secreting cells, so that by taking the pancreas of a fotal calf at the appropriate age, the destructive agent was absent. But it was clear that these methods could only afford a small supply. Hence attempts were made to discover a means of preparation from the ordinary ox pancreas. Dr. Collip was finally successfully by making use of alcohol. The active principle, which it is proposed to call "insulin," is soluble in alcohol of a strength such as to precipitate enzymes, proteins, and probably other substances, although, like secretin, it is insoluble in absolute alcohol. This latter fact gives opportunity for further purification from lipoid. It is finally obtained in solution in physiological saline, suitable for subcutaneous injection. The absence of protein is necessary for clinical use, because of the possibility of anaphylactic shock, if the injections were omitted for a time and then resumed.

Passing next to the properties of insulin, it was found that if injected subcutaneously into animals made diabetic by removal of the pancreas, or indeed hyperglycæmic in any way, the sugar content of the blood was reduced and the glycosuria abolished. Moreover, a very interesting fact was discovered. The blood sugar can be reduced in normal animals by insulin, but if it falls below a certain level (about 0.045 per cent. in rabbits), nervous symptoms come on, and the animal may die in convulsions. These symptoms are at once removed by injection of glucose. Thus the normal activity of the central nervous system depends on the presence of a sufficient concentration of sugar in the blood. It is probable, therefore, that sugar is burned in the brain, and possibilities of investigating the energy value of the cerebral processes associated with mental activity open before us. The fact, however, causes a difficulty in the clinical use of insulin. If too large a dose be given, or it be absorbed too rapidly, nervous symptoms make their appearance. Fortunately, they are unmistakable by the patient, who can at once have recourse to the sugar basin.

Another important action of insulin is to reduce or abolish the presence of acetone and its derivatives in the blood and urine-a characteristic sign of the diabetic state. These compounds have a toxic action on the nervous system, finally leading to coma and death. They are the result of incomplete combustion of fat, and are present whenever insufficient sugar is being oxidised-in carbohydrate starvation as well as in diabetes. It is an interesting fact that neither fat nor protein can be properly utilised without carbohydrate. The oxidation of the former appears to be a kind of "coupled reaction " with that of sugar, and we therefore ask what is the common component? Pyruvic acid or aldehyde, as a stage in the oxidation of both, has been suggested. Vahlen put forward the view some years ago that the function of the pancreatic hormone was to convert glucose into a simpler compound more easily oxidised. These possibilities may be accessible to experiment in vitro by the use of concentrated solutions of insulin. According to some recent work by Winter and Smith in the Biochemical Laboratory at Cambridge, it seems that $\gamma$-glucose, the reactive ethylène-oxide form of glucose, is the first stage, insulin acting as the activator of some enzyme in the tissues. In the normal state, the blood sugar is in the $\gamma$-form, presumably not in diabetes.

The failure to make use of protein in the absence of concurrent oxidation of glucose may have some bearing on another characteristic of the diabetic state - the imperfect healing of wounds. It is pointed out by Dr. Formiguera in the British Medical Journal of December 9 last that insulin will be of much value in making possible the performance of necessary operations in the diabetic - a matter otherwise not to be done. Prof. Starling has suggested that its use may also make it feasible to transplant grafts of fœtal pancreas into such cases. Although the work of Leo Loeb has made it clear that tissues from another individual, unless a very closely related one, degenerate sooner or later when transplanted, embryonic tissues are not so extremely individualised, and the experiment is worth trial.

Insulin confers on the diabetic liver the power of storing glycogen.

Since the capacity of oxidising glucose is deficient in the diabetic animal, an injection of glucose does not raise the respiratory quotient; whereas if insulin be given at the same time this happens. Thus we have the proof that glucose is actually burned and not caused to disappear in some other way. It is further shown by Hepburn and Latchford that the excised heart of the rabbit consumes more glucose if insulin be added to the perfusing solution. Unfortunately, it was not shown that the respiratory quotient was raised, and the authors have overlooked the fact that Starling and Evans in I9I4 found in some cases that the respiratory quotient of the diabetic heart was raised by the addition to the blood of an acid extract of the pancreas. It may be remarked that trypsin being inactive in acid solution, it was thought to avoid destruction of the hormone in this way. Indeed, although it is actually destroyed in an alkaline solution of trypsin, it is not certain whether it may not be oxidised, or destroyed by some agent other than trypsin itself.

Insulin, given to diabetic patients by subcutaneous injection, is found to have the same effects as in animals, together with an unmistakable improvement in condition. Apart from its relieving the serious 
symptoms actually present, it is greatly welcomed in place of the "starvation" treatment of Allen, the only other treatment of value. But it is evident from what has been said above that there is much to be found out in respect to its practical use. Since only a small dose can be given at one time, because of the nervous effects of too great a reduction of the blood sugar, and since the effect only lasts about twelve hours, it is clear that two subcutaneous injections per day are necessary. Although it may be said that people addicted to morphine or cocaine use the process as often as this; the difficulty is not to be overlooked. If the morbid condition of the pancreas has not advanced too far, it may turn out that insulin "relieves strain," as it were, so that the normal state may ultimately be restored. But this has not yet been ascertained. Destruction by the pancreatic juice makes insulin ineffective if taken by the mouth. Perhaps some method may be found by which it may be caused to be absorbed by the stomach before being destroyed. The supply on a large scale involves problems, moreover, which do not arise in the small scale operations of the laboratory.

Here we meet with the knotty question brought into prominence by the action of the University of Toronto in taking out a patent and offering the rights in this country to the Medical Research Council. According to the statement published by this body in the Times of November 17 last, the gift has been accepted, and application for a patent in this country has been made by the University of Toronto. It may well be that this University does not altogether realise the fact that there is a strong feeling here against patenting products of value in the cure of the disease, so that the action of the Medical Research Council is viewed with some degree of misgiving. It is plain that the more work there is done both on the properties and on the modes of preparation of pancreatic extracts the better. While it would be absurd to suggest that the Medical Research Council has any desire whatever to obstruct such research, the necessity for any laboratory being unable to do this except by arrangement with the patentees does not seem desirable. The best modes of large scale preparation would surely be discovered in the shortest time by ensuring that any firms having the necessary plant may be free to make any experiments that may seem promising. Every credit must be given to the Medical Research Council in its desire to protect the public from the results of putting on the open market preparations of unknown potency, some inactive, others too powerful. The words used by the Council may be quoted: "The intention of the Council is to promote, in the light of recent experience in Canada, and of such new knowledge as research will gain, whatever enterprise or organisation is best fitted for securing the earliest production of the Insulin extract under proper conditions of safety and control, and so to facilitate, with the least possible delay, a thorough and scientific trial of the new treatment in this country."

We may ask, would not the best way to effect these objects be to announce that the Medical Research Council were prepared to test and certify preparations sent to them? It may be objected that a large amount of work would be involved in the testing. of numerous small batches, since the only method known as yet requires the use of rabbits. Here is room for investigation, but in the meantime the difficulty might be avoided by refusing to certify any but large batches. If the Medical Research Council were satisfied that a particular firm had the facilities for making such tests themselves, they might agree to accept this firm's own tests, it being always understood that any preparation was liable to control, and a failure to confirm the makers' statement would be ruinous to their reputation.

But there is a further reason that seems to the writer to make such a course the wiser one. The well-meant gift of Toronto University has unquestionably put the Medical Research Council in a somewhat awkward position. In view of the facts referred to in the earlier part of this article, namely, that active extracts have already been made in this country and methods published, it is clear that any general patent could not be upheld. If Collip's special process were patented, it would be open to a maker to vary the solvent, say by using acetone. The writer has found that acetone is less injurious to enzymes than alcohol is, and it might be worth testing for the purpose of preparing insulin. Even if a patent were granted, it would be a very costly and troublesome process to prosecute for infringement, whereas failure to satisfy the Medical Research Council's test would prevent the sale of any worthless preparation. It is indeed quite possible that the objection taken to the apparent policy of this Council is based on a misunderstanding, and that it will turn out that this policy is essentially what is advocated here.

There is another aspect of the matter which has been brought to notice somewhat acutely by the special circumstances of this case. Whatever may be the object of the University of Toronto, there can be no manner of doubt that those who have given time to, and been put to pecuniary loss by work for, the benefit of humanity ought not to suffer. I am informed that Dr. Banting gave up his medical practice to devote his whole time to the research. It may perhaps be objected that if he returns to practice with the reputation gained, large numbers of patients will come to him. But this does not affect the principle. If discoveries in the medical sciences are not to be patented, the question arises as to how their discoverers are to be rewarded. It is absurd, as well as deterrent, to allow the mental capacities which applied to industry would have brought a fortune, to go unrewarded in science. Men of science do not expect fortunes, but freedom from worry is essential for good work, and would well repay the comparatively small expenditure involved.

It may be remembered that about three years ago a combined committee of the British Science Guild and the British Medical Association considered the problem, and a deputation from them was sympathetically received by $\mathrm{Mr}$. Balfour (now Lord Balfour). Subsequent needs for economy prevented any further action. Naturally, many difficulties as to points of detail arise, such as whether a single gift, on the lines of the Nobel prizes, or annual grants, would be the better method. Again, it may be said that a particular discovery is necessarily based on the work of many predecessors. Or a man's work may not lead at once 
to any discovery of practical value, although the foundations of future valuable discoveries may be laid. There is much to be said in favour of rewards for good work done, as well as for providing means for doing it. It would probably be found in practice that the difficulties are not so great as might appear. It may be suggested that funds might be voted to the Medical Research Council and to the Department of Scientific and Industrial Research for the special purpose indicated.

\section{The Identity of Geber.}

\section{By E. J. Holmyard, Clifton College.}

$\mathrm{T}^{\mathrm{T}}$ is generally agreed that the masterpieces of 1 medieval chemical literature are the "Investigation of Perfection," the "Sum of Perfection," the "Invention of Verity," and the "Book of Furnaces," ascribed to "Geber, the Most Famous Arabian Prince and Philosopher." They are written in clear and definite language and are free from the enigmas and allegories which disfigure so large a proportion of alchemical books, and they contain much precise chemical information. The earliest Latin manuscripts of these works appear to be of the late thirteenth century, and they profess to be translations from the Arabic of Jäbir ibn Haiyān, who lived in the eighth century A.D.

The Arabic origin of Geber's works was universally accepted until the middle of the nineteenth century, when Kopp first expressed doubts as to their authenticity. Kopp, however, knew no Arabic and was not acquainted with any Arabic works of Jäbir, so that his suggestion was merely tentative. Additional evidence was secured by Berthelot, who caused translations to be made of a few Arabic manuscripts containing works ascribed to Jābir ibn Haiyān, and compared these translations with the Latin works mentioned above. He came to the conclusion that Geber's works were European forgeries of the thirteenth century and could certainly not be regarded as translations of works of Jābir ibn Haiyān. Ûp to the present no one has challenged Berthelot's conclusion, and all historians of chemistry have followed him blindly, without critical examination of the material upon which his conclusion was based. I hope to show in the present article that there is a good deal more in the problem than Berthelot seemed to realise, and, while not claiming to have proved definitely that Geber and Jābir are identical, I believe that the evidence now accumulated renders this identity extremely probable.

It is necessary in the first place to consider the data which Berthelot had at his disposal, and to estimate their value; and secondly, to enumerate the definite points in his argument. A fact of prime importance is that Berthelot was completely ignorant of Arabic and was therefore not in a position to draw conclusions from considerations of style--yet this is what he continually attempted to do. This habit of Berthelot's has been severely criticised by von Lippmann ("Entstehung und Ausbreitung der Alchemie," Berlin, r9r9), and I need not enlarge upon it here.

Berthelot's acquaintance with Arabic alchemy was limited in two senses, for, in addition to his want of knowledge of the language, he knew even in translation only thirteen small works, nine of which are attributed to Jäbir. While, therefore, one has the greatest admiration for Berthelot's invaluable pioneer work, one is justified in holding that the foundation of the edifice which he reared is somewhat insecure. The more I investigate the subject the more do I feel, with Berthelot's countryman Prof. E. Blochet, that "il faudrait des années d'un labeur ininterrompu pour tirer des manuscrits la doctrine arabe de la chimie." 1

According to the "Kitāb al-Fihrist," a Muslim encyclopædia of the tenth century A.D., Jābir wrote at least five hundred books, some large and some small. About fifty of these are known to exist, and I have no doubt that many others could be found by diligent search. A study of the extant manuscripts shows that Jäbir was very catholic in his learning-he was at once philosopher, physician, mystic, and chemist. It so happens that Berthelot came upon some of the more mystical of Jābir's works, and was therefore led to a wrong conclusion as to his attainments in chemistry.

To come now to the definite points in Berthelot's argument. It- will be convenient to give these so far as possible in his own words ("La Chimie au moyen âge," tome i.).

I. La première et la plus essentielle, c'est que le texte arabe renferme certaines des doctrines précises sur la constitution des métaux, que nous trouvons dans les textes latins réputés traduits de l'arabe et attribués [à Geber] ; tandis qu'une autre partie de ces doctrines manque complètement dans les traités arabes et paraît dès lors appartenir à une période plus moderne. Ainsi la doctrine des qualités occultes, opposée aux qualités apparentes, est formellement exposée dans les textes arabes de Djâber [Jãbir]. . . . Au contraire, aucune allusion n'est faite dans les textes arabes précédents à la théorie de la génération des métaux par le soufre et le mercure.

2. On ne rencontre... dans les œuvres arabes de Djâber, de recette précise pour la préparation des métaux, ou des sels, ou de quelque autre substance.

3. Dans ces traités arabes, le langage est vague et allégorique.

4. Aucune doctrine ou fait précis n'est énoncé, aucun personnage n'est cité.

5. (No direct quotation of Geber is made by Albertus Magnus or 'Viricent de Beauvais, the presumption being that the Latin works of Geber were therefore not known to these two alchemists.)

6. La Summa ne contient ... . aucune des formules musulmanes . . . dont [Jäbir] est prodigue.

7. (The Summa contains an account of the arguments of those who denied the possibility of transmutation. Of this " on n'en trouve aucune trace dans les opuscules arabes de Djâber.")

8. (The style of the Summa recalls that of the Schoolmen.)

9. L'auteur (of the Latin works) dit que, d'après lui, il existe, en réalité, trois principes naturels des métaux: le soufre, l'arsenic qui lui est congénère, 1 Private communication to the author. 